\title{
Students Voices: A Qualitative Study On Teachers' Written Feedback Among Fourth Year University Students
}

\begin{tabular}{|c|c|}
\hline & $\begin{array}{l}\text { Syamsul Bahri }^{\mathbf{1}} \\
\text { y State Islamic University of Banda Aceh }\end{array}$ \\
\hline ARTICLE INFO & \multirow{2}{*}{$\begin{array}{l}\text { ABSTRACT } \\
\text { The obiectives of this study is to find student's voices on teachers' }\end{array}$} \\
\hline Article history: & \\
\hline Received Sep 28, 2018 & \multirow{9}{*}{$\begin{array}{l}\text { The objectives of this study is to find student's voices on teachers' } \\
\text { written feedback. The qualitative study investigates the student's } \\
\text { voices on teachers' written feedback of their essays and comments } \\
\text { that benefit students' future improvement as writers. It explores } \\
\text { sixty-one English Department students' opinions on the written } \\
\text { feedback of their writing teachers at Ar-Raniry State University of } \\
\text { Islamic Studies, Banda Aceh, Indonesia. The findings indicate that } \\
\text { writing teachers provide various kinds of feedback on students' } \\
\text { essays and they valued positive teachers' feedback on all aspects of } \\
\text { writing such as grammar, mechanics, content and organisation. } \\
\text { Teachers' negative comments were also considered useful for } \\
\text { students' learning because they can help students to improve their } \\
\text { critical thinking and writing skills. In addition, for student future } \\
\text { improvement, teachers' feedbacks do contribute to learning and that } \\
\text { teachers' feedback on grammar and organisation are more } \\
\text { preferable than those on content and mechanics. It is suggested that } \\
\text { feedback which highlights strengths and weaknesses of students' } \\
\text { work can facilitate students to learn and make better future learning. }\end{array}$} \\
\hline Revised Jan 02, 2018 & \\
\hline Accepted Jan 02, 2019 & \\
\hline & \\
\hline $\begin{array}{l}\text { Students voices, } \\
\text { teachers' feedback, } \\
\text { future learning }\end{array}$ & \\
\hline Clonflict of Interest: & \\
\hline None & \\
\hline Funding: & \\
\hline None & \\
\hline
\end{tabular}

Corresponding Author: Syamsul Bahri is a postgraduate (Doctorate Student In Applied Linguistic of English) in State University of Medan (UNIMED) Indonesia. He earned (S. Ag.) Bachelor Degree (Majoring English Education) from Ar-Raniry State Intitute of Islamic Studies in Banda Aceh, and MA in TESOL from Canberra University, Australia. He can be contacted by email: syamsul.bahri@ar-raniry.ac.id

Copyright $@$ Association of Language Teachers in Southeast Asia. All rights reserved

\section{INTRODUCTION}

Teachers' written feedback is an important element in the learning cycle in academic life, providing for reflection and improvement. Teacher written feedback, which highlights strengths and weaknesses of students' work, can provide the means by which students can learn and make improvement to future work. (Weaver, 2006). Regardless of a wide variety of perceptions toward the effectiveness of such feedback, teacher written feedback continues to be generally accepted.

Written comments of a teacher, also known as feedback, is important not only in developing students' motivation and but also in promoting learning. Positive comments contribute to motivation and usually, but not always, to the learning. Positive comments are usually constructive: for example, "well expressed", is constructive in terms of motivation but probably not to learning because students cannot get sufficient information from such a brief phrase. However, if the written comments are more complete they can add to the students' learning. For instance, "well expressed, I like your clear sentences and appropriate word choices" Negative and complete comments do not usually contribute to motivation but they can be constructive for learning, for example "not well expressed, your sentences are too simple and your vocabulary is not always appropriate." To understand more fully whether or not teachers' written comments are positive and helpful, this study will explores the perception of English Department students from 
various writing classes. This study pose three questions: 1). Do English Department Writing Teachers provide written feedback on their students paperwork? 2). To what extent English Department students find positive or negative feedback from their Writing Teacher? 3). What kind of comments are percieved more beneficial for English Department Students' future improvement in their writing?

There are two underlying academic imperatives which have motivated this study: theoretical and pragmatic. Theoretically, the study of written comments specifically is still relatively new (Goldstein, 2004), so Mutch (2003) calls for further research into how students respond to feedback. The pragmatic motivator is that more research focusing on students' responses and preferences is needed (Hamp-Lyons, 2003).

On the personal level, providing written comment in detail seems not common practice among English Department EFL teachers. It is assumed that there are several possible reasons for this. Large classes, which comprise up to 35 students or more constitute a typical classroom in Indonesian EFL setting, and this can compromise teachers' ability to give feedback. Another drawback is that lack of teaching staff may require one teacher to teach up to five subjects. In these cases, teachers may not have enough time to provide detailed comments on students' work. Actually, providing written feedback may be seen as a dialogue between a Teacher and a student in learning. Therefore, the lack of feedback would restrict the important of communication and may inhibit the learning process.

This study aims to find out whether writing teachers of English Department of Ar-Raniry State Institute for Islamic Studies provide written feedbacks on students'worksheet and to explore students' opinions on the written comments of their writing teacher. The study focuses on English Department students' responses to positive and negative feedback on their assignments and preferred comments that benefit students' future improvement.

\section{REVIEW OF LITERATURE}

Feedback that its definition has been mentioned in the previous chapter plays significant role in both ESL and moreover in EFL teaching and learning as Hyland and Hyland $(2006,83)$ mention that "Feedback has long been regarded as essential for development of second language (L2) writing skills, both for its potential for learning and for student motivation". In process based, for example, learner-centered classroom, feedback is seen as a vital developmental tool moving learners through multiple darfts towards the capability for effective self-expression. Probst (1989) as quoted by Hyland and Hyland (2006) see it from interactionist perspective that feedback is regarded as an important means of establishing the significant of reader responses in shaping meanings. In genre classrooms, feedback is a key element of the scaffolding provided by the teacher to build learner confidence and the literacy resources to participate in target community.

Students expect a certain amount of feedback because they have spent much effort and time in writing the paper. As Iron $(2008,55)$ asks, 'How many times have students complained because they put so much time and effort into a piece of work only to receive a small amount of written feedback?' Another feature of the feedback usually given on student written assignments is that the comments are negative. They commonly focus more on the weaknesses and ignore the strengths of the students' work. As a result, the students are more familiar with negative feedback.

Negative feedback often leads to students' being discouraged and having lowered motivation. As Spandel and Stiggins (1990) as cited in Haines $(2004,22)$ have stated 'negative comments, however well-intentioned they are, tend to make students feel bewildered, hurt or angry...' (and) 'Positive comments build confidence and make the writer want to try again'. In similar vein, Penny Ur $(1996,253)$ states, 'it is essential for such assessments to be given in an atmosphere of support and warm solidarity, so that learners feel that the teacher's motive is honestly to promote and encourage their learning, not to put them down'.

There have been several studies about students' responses on teachers written comments. Ferris (2003) has provided the summary of survey findings in this area. The first study made of students' perception of teacher-written feedback was conducted by Cohen (1987). His research questions 
asked what teacher feedback deals with; how much students process feedback on their work; what strategies the students use to cope with teacher feedback; and the problem they have in interpreting teacher feedback. Having surveyed 217 students from various university language classes, Cohen found that the students read and attended to feedback and they felt that teachers did and should focus their feedback on local issues (such as grammar and mechanics) rather than on global writing issues (such as ideas, content, and organisation). The respondents in this study also value laudatory comment positively (Cohen, 1987).

Conversely, Radecki and Swales (1988) conducted a research on student attitudes toward teacher commentary. They surveyed fifty-nine university students in four different levels of writing classes. They found that students were initially more concerned with their grades than the comments they received on their essays, but also have positive attitudes and have very appreciative reactions to teachers' written comments, then they grouped the students into "Receptors", "Semi-resistors", and "Resistors". Radecki and Swales $(1988,358)$ concluded that most of the ESL students prefer comments that were "content specific".

In addition, Cohen and Cavalcanti (1990), who did a replication study on Cohen (1987) found that students were generally pleased with teacher feedback and that the students wanted feedback on all areas of writing. Another researcher who did a replication study of Cohen's work (1987) is McCurdy (1992). Her findings were similar to previous studies in which students reported being happy with feedback given and also found it valuable for their writing development. Ten years after the first study on students' response on teacher commentary, Ferris (1995) who revisited the study of Cohen (1987) and McCurdy (1992), found a similar result. Ferris concluded that students are very appreciative of teacher feedback and find it helpful. She also found that students are more attentive to feedback given during the writing process instead of after they have already finished a composition. The findings suggest that students have a strong preference for local feedback (Ferris, 1995b).

Straub (1997) specifically asked students for their beliefs about the most useful way for the teacher to respond by surveying 142 first year college Writing students. The survey introduced nine categories of teacher comments but only two are relevant to the present discussion; criticism and praise. Straub (1997) infers that students preferred comments that were more like reader than teacher responses. On the other hand, students always welcome teacher's praise in their paper, but the praise that they want is the one that is specific and also accompanied by explanation of what the teacher saw as "good".

Moving to the area of teaching English as Foreign Language (EFL), Enginarlar (1993) was motivated directly by Radecki and Swales' study and attempted a replication using subjects of forty-seven College students in Turkey. He found that students have very positive feelings toward teacher feedback; making comments such as "Writing comments have lasting effects", "...comments are not humiliating us" (Enginarlar, 1993). Generally, students' responses are similar to the study of Radecki and Swales (1988).

Another EFL perspective is provided by Arndt (1993). He was interested to research students' and teacher's perspectives on feedback in the process of writing classes and he is also keen to determine the major areas of students versus teacher feedback as regards match or mismatch. Having surveyed seventy five college students and eight teachers from Hongkong Polytechnic College, Arndt found that students prefer macro concerns (content and organisation) over micro concerns (linguistic issues such as mechanics, sentence structures).

However, studies investigating student responses to written feedback in both L1 and L2 contexts have shown conflicting results. Leki (1990), in a review of L1 student responses to written commentary, states that students prefer to receive positive feedback; and Semke (1990) found that the teachers' supportive comments instead of corrections appear to have a positive effect on student attitude. However, studies by Burkland and Grim (1984) found that students preferred critical comment over commentary ones. Another study by Burkland and Grim (1986) showed that students had a very indifferent position towards praise, suggesting that it really did not make any significant difference. 


\section{METHOD}

Sixty one (22 males and 39 females) ranging from second to fouth year university students majoring in English Teacher Training of Tarbiyah Faculty took part in the survey, they are the students of English Department of Ar-Raniry State Institute of Islamic Banda Aceh (now become State Islamic University), either who were taking writing unit or had taken writing unit. According to manual book of the university, Writing I, Writing II and Academic Writing courses are available from the fourth semester to the sixth semester consecutively. Two credits offered in each of these courses every semester, with one credit equaling 50 minutes classroom teaching and learning activity

They were asked to response to twenty items questions of questionnaire which consists of three parts: Part One concentrates on demographic information; Part Two concentrates on four ideas; whether or not English Department Teachers provide written feedback; the aspects of written comments that the students valued most, whether the students were more familiar with either positive or negative of teacher comments, and what types of comments that the students perceive as more helpful for their development as writers in the long run. In Part Three, open ended questions were provided to elicit from respondents any new ideas that had not been covered in the previous two.

\section{FINDINGS AND DISCUSSION}

\subsection{Finding}

This study found that writing teachers do provide written feedback on students' essays, as clearly depicted by the following graph.

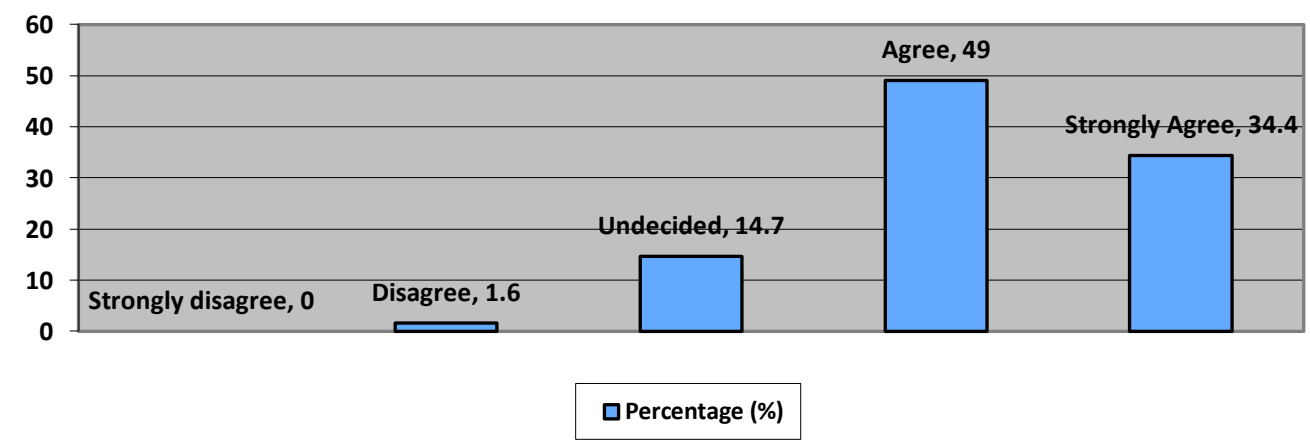

The data shows that the majority of respondents $(83.4 \%)$ say that writing Teachers provide written feedback on students' essays. Only one respondent (1.6\%) ticking disagree on the statement. This finding confirms the result of the observation conducted by Zulfadhliadi (2010) as revealed that the student really received written feedback given.

When it is asked about students' responses of teachers' positive feedback. Most the students valued the aspects of Teacher written feedback was on grammar of the students'essays with $94.9 \%$ of respondents agreeing that these type of comments were useful. Interestingly, the respondents valued aspects of Teacher written feedback on content as useful as they valued mechanics (both aspects get $88.4 \%$ ). Although, the comments on organisation was the least valued aspect among others, the vast majority of respondents $(88 \%)$ choose this option.

Moreover, the open-ended questions data revealed a slightly similar picture in which most of the student respondents fullfilling the form state that the students value comments on grammatical aspect and on content.

When it is asked whether or not positive comments on students'essays can increase their selfconfidence. The findings reveal that positive written comments on the students'essay can contribute to the increase of students' self-confident, with $83.5 \%$ respondents ticking agree and strongly agree. The data from open ended questionnaire release the same tone, as it is written out by a respondent, that is ..."positive feedback can motivate me to be better". (Q.34) 
The findings indicate that English Department students expect their writing Teacher to provide them with written feedback containing requests, information and suggestions. Of the preferences, the students prefer comments that give information a bit more than other options with $78.6 \%$ of respondents ticking "I prefer comments that give information". The vast minority student respondents marked disagree on the preferenced comments.

Dealing with the teachers' "helpful comments". The findings show that the vast majority of the student respondents beleive that praise from teacher is helpful with $81.9 \%$ marked agree and strongly agree on the statement praise-containing comments on students essay are helpful. Only one respondent $(1.6 \%)$ says that praise was unhelpful. The other ten student respondents $(16.3 \%)$ prefer no comment by ticking Undecided.

Whether ot not positive comments can provide motivation for students. The data show that the vast majority of the students respondent (85.1\%) believe that teachers'positive comments can contribute to writer motivation although some other 14 respondents were uncertain about the answer, interestingly, neither marked disagree or strongly disagree on a statement "Teacher's positive comments can motivate students".

However, Dealing with the teachers" "negative comments". The result of the research show that the respondents share percentage between agree and disagree on statement whether Teacher's comments are too much so the students get confused, with $42 \%$ marked agree and strongly agree and $16 \%$ marked disagree. Whilts the other $34.4 \%$ respondents ticked undecided. It seems that for those ticking undecided, they actually tend to be in disagree group.

Moving to the statement whether Teacher's negative comments can cause negative effect on their language confidence. the minority of respondents $(16.3 \%)$ show their disagreement on this statement. But less than half of the respondents beleive that the Teachers negative comment would give negative impact on their language confidence. Whilts $32.7 \%$ of respondents were uncertain about this statement.

Dealing to negative comments are useful, the data show that it is slightly more than a half respondents $(55.7 \%)$ opted agreement that negative comments (critical comments) are useful for learners. The finding also indiicates that negative comments are motivating wiht nearly a half of respondents marked agree and disagree.

Moving to perception of the students whether feedback can facilitate future improvement or not. Students in this study believe that some kingd of feedback are more benefecial for their future improvement than others. The result provide visual representation of the data collected from the students'questionnaire. All of the respondents $(100 \%)$ agreed that the comments on grammatical aspect would be benefecial for students future learning improvement, followed by organisation (93.3), mechanics (88.4), and content (78.6). None of the respondents disagreed and strongly disagreed about either grammatical aspect and mechanics. Only a very small percentage of students respondents $(4.8 \%)$ thought that comments on content and organisation were uninportant for their future development as writers.

However, the open-ended questions data revealed a slightly different picture. There were no dominant answers because the students respondents wrote a wide variety of responses. Only small percentage of respondents put that the comments on grammar and organisation of the essays would be beneficial for students future learning. Most of the them left the open-ended space blank.

Surprisingly, three out of sixty one respondents say that the negative comments (too critical comments) were useful for future learning (Q.9, 37, and 46). But, the researcher is unable to investigate the reasons beyond this statetement because the respondents were marking "no" in the instrument form asking whether they welcomed to be interviewed about their answers.

\subsection{Discussion}

The findings have suggested that these sixty one English Department Students of Ar-Raniry State Institute of Islamic Studies found that Teachers'comments were highly valuable both for learning and motivation. These findings were relevant to some previous studies in which students find teachers'written comentary helpful (Cohen, 1987; Hyland, 1998). The findings also support the 
study of (Radecki \& Swales, 1998; Leki, 1991) in which L2 students want error feedback and believe that they benefit from it.

As indicated in the findings, the student respondents found the teachers'comments about all aspects of writing involving grammar, organisation, content and mechanics to be highly valuable. This study confirms the previous study conducted by Cohen \& Cavalcanti (1990) in which students were generally pleased with teacher feedback and that the students wanted feedback on all areas of writing. The students also found it valuable for their writing development as revealed in the survey of McCurdy (1992).

Regarding aspects of teachers'written feedback, students found that the comments on grammar and organisation were slightly more beneficial for their future development as writers. The students beleived that the positive comments about grammar and organisation would help to develop their standard writing quality. These findings were similar to the result of two earlier studies (Leki, 1991; Radecki \& Swales, 1988). They found that the students generally prefered extensive comments on grammar rather than on caontent. The later study by Hedgcock \& Lefkowitz (1994), they reported a more complex finding, "Foreign language (FL) learners paid more attention on form, whereas ESL students were as interested in teacher feedback as they were in sentence-level comments". To comment on the issue above, the writer borrow an analysis of Ferris (2005). She suggests that this may be due to the fact that whereas FL students use L2 writing as a Form of language practice, ESL students must use their writing skills for all of their academic endeavours (e.g. beyond the language classroom).

The teachers'written comments about organisation were also the second most prefered and the students also beleived that it would be beneficial for their future improvement. As students majoring English, they want to be sufficiently skillful to produce well-organised texts. But, the ability to develop a well-organised written work is not an easy task.

Another interesting finding is that the surveyed students thought that positive comments are more useful than negative onces. But there are slightly more than a half of the student respondents beleived that negative comments are also useful. Although such critical comments often contain critism and negative meaning, they can encourage students to improve their analytical skills. So, at least for matured students as in the present study, it is not always true that critism and negative comments humiliate and hurt students'feelings; they can promote students to think critically and write thoughtfully.

The reason that the students valued positive comments may be because they received feedback from teachers who they thought were competent and qualified in their own fields. The comments that the teachers have written have at least two purposes. They offer assistance of an expert, guiding students through their "zone of proximal development" Vygotsky (1978) and providing opportunities for students to see how others respond to their work and to learn from these responses. Why then would students prefer comments both global issues (content and organisation) and local one (grammar and mechanics)? It seems that the English Department students want to write a "good"essay in "good"English.

\section{CONCLUSION}

As indicated by the data that English Department writing Teachers do provide written feedback in a wide veriety of forms from global issues to local one. These sixty one students found that the writing teachers' written comments were helpful. The data also indicate that students have mostly found positive on feedback provided. The students valued positive teachers' comments on all aspects of writing such as grammar, mechanics, content and organisation. Teachers 'critical comments were also useful for students' learning because they helped students to improve their critical thinking and writing skills. Another interesting result is that feedback/comments given on grammatical aspects and organisation of essays are slightly more beneficial for students' future improvement in their writing in compared to feedback/comments of mechanics and content of essays. 


\section{REFERENCES}

Arndt, V. (1993). Response to writing: Using feedback to inform the writing process. In M.N. Brock and Walter. L. (Eds.), Teaching composition around the facific Rim: Politic and Pedagogy. Clevendon, England: Multilingual Matters.

Barnes, A. (1999). Assessment. In Pachler, N. (1999). (Ed). Teaching modern foreign languages at advanced level. London: Routledge.

Burkland, J. \& Grimm, N. 1986. Motivating through responding. Journal of teaching writing, 5.

Cohen, A., and Cavalcanti, M. (1990). Feedback in written compositions: Teacher and students verbal reports. In Kroll, B (ed.) Second Language Writing: Research Insights for the Classroom. Cambridge: Cambridge University Press.

Cohen, A., D. (1987). Students Processing of Feedback on Their Compositions, In: Wenden, A. and Rubin, J. (1987). Learning Strategies in Language Learning. Prentice Hall International.

Enginarlar, H. (1993). Students response to teacher feedback in EFL writing. System, 21 (2). 193 204.

Ferris, D. (1995b). Students reactions to teacher response in multiple-draft composition classrooms. TESOL Quarterly, 29, 33-53.

Ferris, D. (2003). Response to student writing: Implications for second language students, New Jersey: Lawrence Erlbaum Associates, Publishers.

Goldstein, L.M. (2004). Questions and answers about teacher written commentary and student revision: teachers and students working together. Journal of Second Language Writing 13. $63-80$.

Haines, C. (2004). Assessing Students' Written Work: Marking Essays and Reports, New York: Routledge.

Hamp-Lyons, L. (2003). Writing teachers as assessors of writing. In Exploring the dynamics of second language writing, Kroll, B (ed.). Cambridge: Cambridge University Press.

Hedgcock, J., \& Lefkowitz, N. 1994. Feedback on feedback: Assessing learner receptivity in second language writing. Journal of Second Language Writing, 3.

Hyland, K. (2003). Second Language Writing. Cambridge: Cambridge University Press.

Hyland, K., and Hyland, F., (2006). Feedback on second language students'writing, Cambridge: Cambridge University Press.

Iron, A. (2008). Enhancing Learning through Formative Assessment and Feedback, New York: Routledge.

Jack C. Richards, et.al., (1992). Longman Dictionary of Language Teaching \& Applied Linguistics, Harlow: Longman.

Kroll, B. (2003). Exploring the Dynamics of Second Language Writing, Cambridge: Cambridge University Press.

Kroll, B. (ed.) (1990). Second Language Writing: Research Insights for the Classroom, Cambridge: Cambridge University Press.

Mutch, A. (2003). Exploring the practice of feedback to students, Active Learning in Higher Education, 4 (1), 24-38.

Radecki, P.M. and Swales, J.M. (1988). ESL Student Reaction to Written Comments on Their Written Work, System, 16(3), 355-365.

Semke, H. D. (1984). The effects of the red pen. Foreign Language Annals, 17 (3) 195-202.

Sommers, N. (1982). Responding to Student Writing, College Composition and Communication, 33 (2), 148-156.

Straub, R. 1997. Students'reactions to teacher comments: An exploratory study. Research in The Teaching of English.

SALTeL Vol. 2, No. 1, 2019: $42-49$ 
Sujana, (1985). Metode Statistika, Bandung: Tarsito.

Ur, P.1996. A Course in Language Teaching, Cambridge: Cambridge University Press.

Vygotsky, L. S. 1978. Mind in Society, Massachusetts: Harvad University Press.

Weaver, M.R. (2006). Do students value feedback? Student perceptions of tutors' written responses. In Assessment \& Evaluation in Higher Education, 31 (3), 379-394.

Zamel, V. (1985). Responding to students writing. TESOL Quarterly, 19, 79-102.

Zulfadhliadi (2010). Students' perception on their Teacher written feedback. Unpublished Skripsi. Tarbiyah Faculty IAIN Ar-Raniry. 